\title{
The Effectiveness of Topic-Based Writing on EFL Learners' Writing Skill
}

DOI: https://doi.org/10.47175/rielsj.v1i3.138

\section{| Nguyen Thi Dung |}

Lecturer of English, Binh

Thuan Province Vocational

College, Vietnam

ntdung@dnbt.edu.vn

\begin{abstract}
Being accepted as out of the four essential language skills in the language learning process, writing seems to be difficult for numerous EFL learners. This research is an endeavor to explore if learners can grow out of the writing difficulties with topicbased writing activity. 78 third-year students at the Faculty of Foreign Languages of Phan Thiet University in Phan Thiet City, Binh Thuan Province participated in the study. These students were in the two writing classes, one class was treated as the experimental group (EG) and the other as the control group (CG). Research findings exposed the benefits of topic-based writing activity in nurturing learners' writing motivation and enhancing their writing skill. Furthermore, this activity gave students good chances to widen their knowledge on the topic, enrich their emotion on disadvantaged people, and build a friendly learning environment outside the classroom. The necessity and usefulness of the application of topic-based writing activity was predominantly recognized among students. KEYWORDS

Topic-based writing; writing skill; English as a Foreign Language (EFL) learners
\end{abstract}

\section{INTRODUCTION}

English writing, the last language skill to be obtained not only for native speakers but also for foreign/second language learners (Hamp-Lyons and Heasly, 2006), for a variety of EFL learners, appears to be demanding. It is too challenging to produce and shape ideas choosing appropriately the organization of vocabulary, sentence and paragraph, and then place such ideas into an understandable text (Richard and Renandya, 2002). Meanwhile, being successful in English writing benefits EFL learners in both their English learning and life-long careers as Glazier (1994: 3) states "Being able to write in English is essential in college, and it probably will be an asset in your career."

However, being asked to perform writing tasks within a certain span of time in the classroom is also another challenge hindering learners' writing effectiveness. Weir (1990) explains that time pressure is usually unrealistic for extended writing because before producing the last complete version; nearly all of people need more time to solve several tasks.

Besides, the character of writing is not fascinating enough for a preponderance of English learners to practice frequently (Hedge, 1991). In this respect, Hamp and Heasley (2006) contend that few people write encouragingly and have a sense of comfort with a writing task coming under the eyes of others.

While Tho (2000) claimed that maybe non-native writers do not have enough ideas or even do not have anything to write down, Hidi and McLaren (1990 \& 1991) found that the production of written texts was influenced by the attractiveness of the topic. These authors gives an understanding glimpse that the level of the topic interest leaves positive effects 
on the quality and quantity of the written products thanks to knowledge factors, that is to say, what learners know about the field they were asked to write about.

Since 1980s, the elaborative function of writing, that is, the effects of writing on a writer's learning and thinking processes, has been focused in many studies in which the writing to learn and discourse synthesis were the two main research lines.

What Emig (1977) supposed about writing to learn in 1977 was cited by Boscolo et al. (2007: 76): "In the studies of writing to learn, the thing must be emphasized in the role of writing as a thinking and the learning instrument, and the researcher's attention is focused on the effect of writing on the comprehension of information." Studies on writing to learn supposed that writing has impacts on students' learning and thinking, as writers are obliged to explore the ideas being written about (Applebee, 1984). Newell's (1984) confirmed that students gain more knowledge on a scientific topic and are engaged in planning, organizing, and reasoning when writing an essay on a topic.

The term discourse synthesis is the process in which writers are involved in reading texts and creating a new one (Spivey \& King, 1989). This process includes three basic operations: (1) collect the information, (2) organize the information, and (3) connect the information to achieve a text (Stahl et al., 1996). As writers uses cues from reading texts to produce the written text, discourse synthesis consists of comprehension and composition processes (Spivey, 1997). Thus, a written report can be accepted as a comprehension task as well as a production task.

This research examined if EFL learners can be more successful in writing in terms of accuracy, fluency, achievement, and motivation by engaging in topic-based writing in combination with reading texts on that topic.

\section{RESEARCH METHODS}

78 third-year students, 51 females and 27 males attending the third writing course (Writing 3) at the Faculty of Foreign Languages of Phan Thiet University in Phan Thiet City, Binh Thuan Province were invited to join this study. These students were from the two thirdyear classes, ranging from 20 to 25 years old and, were of the same writing proficiency level, based on the students' scores from the pretest (see Table 1).

One class (K16.2) with 42 students was treated as the experimental group (EG), and the other (K16.5) with 36 ones as the control group (CG). The students in the EG were immersed in topic-based writing at home in addition to in-class writing activities, which the students in the CG were required to accomplish.

University and class permission for the participation was obtained before starting doing research. Participants were briefly introduced to the objective of the study.

To get insight in fluency and accuracy in writing proficiency level of students, pretest and posttest in the form of essay writing were used. The pretest was employed to measure the writing proficiency level of all third-year students at Faculty of Foreign Languages, and then the EG and CG were chosen based on the results of this test.

Students in EG received a list of articles, formal links concerned about the topic they are going to write about, subtopics should be written within 11 weeks. In this study, ASD (Autism Spectrum Disorder) is regarded as the topic for learners to follow in the writing process to meet the requirements on writing techniques of each weekly lesson.

This topic was chosen for students to write about because of the researcher's wishes for more awareness of this syndrome among Vietnamese youngsters. In fact, there has recently been an increase in the amount of children diagnosed with ASD in Vietnam (CLAN 2010). Nonetheless, deep understanding of ASD in this nation is still limited. (Brown, 2009). On social networks, several groups of parents with autistic children call for the sharing of 
society on this problem. In addition, during eleven-week-writing course, from March, $4^{\text {th }}$ to May, $13^{\text {th }}$ 2019, there came the World Autism Awareness Day when the international community carried out activities in recognition of people with autism and those who love and support them. Thus, through practicing writing, the researcher wanted students to care about this social event and ASD, be responsible to disadvantaged people and society.

Besides, they were required to compose what they thought and felt over writing about ASD in three writings which were done at the beginning, at the middle, and at the end of the course.

As all EG students had mobile phones connected with the Internet, and they had been exchanging all their learning information through this electronic device. Hence, they were asked to use phones to interact when participating in this study. Thanks to the Zalo application, a premier chatting platform which is quite common in Vietnam, a Zalo group whose members were the researcher and EG students was created so that students submitted their writings within 11 weeks between the pretest and posttest, the researcher could give feedback at the weekend and all discussions on ASD and writing strategies were carried out. Weekly, students sent what they asked to write to the researcher within 5 days, from the class meeting day, the researcher gave them comments and recorded any changes in writing fluency, accuracy, and writing motivation made by the students as well as the signs to show that their knowledge and sentiment on ASD were improved.

Students in both EG and CG sat for the posttest at the thirteenth week, which sought to assess the impact of topic-based writing. Nevertheless, only the students in the EG were inquired to give answers for the questionnaire survey (see Table 2) which collected their reflections upon topic-based writing and the usefulness of reading on writing.

\section{RESULTS AND DISCUSSION}

All 78 participants (42 learners in EG and 36 ones in CG) submitted essays in both pretest and posttest which each lasted 45 minutes. The results of pretest and posttest in EG and CG proved benefits of topic-based writing activity on learners' writing accuracy, fluency and achievement.

\section{On Learners' Writing Accuracy}

Accuracy in this study was regarded as the ability to avoid error in performance. In some extent, it revealed better levels of language control.

At the beginning of topic-based writing practice, there was no distinct divergence in the writing accuracy level of all students. As displayed in Table 1, the gap in the average number of mistakes between the two groups was 0.95 . In average, the amount of mistakes made in the pretest by the students in the CG was 23.12 and that in the EG was 24.07.

Nevertheless, after eleven-week practice of topic-based writing, in the respect of writing accuracy, the EG students proved the better movement than those in the CG. In the EG, the average number of errors left by the students decreased by 15.93 mistakes in the posttest compared with the pretest, while that in the CG fell by 6.79 mistakes. Briefly speaking, the average number of errors made by the students was markedly different between the two groups.

\section{On Learners' Writing Fluency}

In this study, writing fluency was considered as the number of words produced within a limited length of time, 45 minutes and the level of task completion. Prior to participation in topic-based writing activity, the writing speed of the students in two groups was nearly 
equivalent. The result of the pretest demonstrated that, in the CG, students produced 193.30 words in average while this number was 190.21 in the EG. Therefore, the difference in the average number of words written was 3.09 words.

Nevertheless, there was a noticeable difference in the average number of words generated by the students in both groups after eleven weeks which could be clearly seen from the results of the posttest. In the EG, the difference in the average number of words between the posttest and the pretest was 18.76 words whereas that in the CG was 7.32 words. In other word, there was a higher improvement in the students' writing pace in the EG compared with those in the CG.

In addition, while in the pretest, the numbers of CG students could not complete the essays was 8 while that number in the EG was 10 . However, in the posttest, only 3 EG students submitted the unfinished essays meanwhile up to 5 CG ones could not finish their writing in time. It was obvious that regarding to writing task completion, in the EG, the students improved higher than those in the CG.

\section{On Learners' Writing Achievement}

Related to average pretest score, as illustrated in Table 1, there was a minor disparity between the two groups. The average pretest point of students in the EG was 6.31 and that in the CG was 6.42 .

However, in term of the average posttest scores, there was a considerable divergence in these groups. In the EG, the average posttest score went by 1.53 points compared with the average pretest score, while that in the CG grew only by 0.43 points in comparison with the average pretest score. In a nutshell, the results in the EG have been clearly improved.

Table 1. Results of tests

\begin{tabular}{|l|c|c|c|c|}
\hline \multirow{2}{*}{ Items } & \multicolumn{4}{c|}{ Tests } \\
\cline { 2 - 5 } & \multicolumn{2}{|c|}{ pretest } & \multicolumn{2}{c|}{ posttest } \\
\cline { 2 - 5 } & EG & CG & EG & CG \\
\hline Average points & 6.31 & 6.42 & 7.84 & 6.85 \\
\hline Average number of errors in an essay & 24.07 & 23.12 & 8.14 & 16.33 \\
\hline Average number of words in an essay & 190.21 & 193.30 & 208.97 & 200.62 \\
\hline Number of uncompleted essays & 10.0 & 8.0 & 3.0 & 5.0 \\
\hline
\end{tabular}

\section{Results From the Questionnaire Survey}

This questionnaire survey was answered by all 42 learners in EG to explore the benefit of topic-based writing activity on learners' writing motivation.

The data from Table 2 with 34 positive responses $(80.95 \%)$ to question 1 and 31 positive responses $(73.81 \%)$ to question 2 demonstrated that EG students not merely were attracted by the topic-based writing but also were aware of its helpfulness in their writing learning. Besides, on the whole, reading was considered to be necessary for students to write independently. There was $90.48 \%$ of them read about the topic before writing.

The result showed that $35.71 \%$ of students in the EG said to write about the topic over an hour daily, and $50.00 \%$ of them spent about 45 minutes on topic-based writing per day. This led to the conclusion that many EG students concerned about topic-based writing regularly.

Furthermore, 36 out of 42 the students in this group (85.71\%) were eager to continue with topic-based writing activity after the writing course substantiated that the intrinsic motivation in topic-based writing was shaped in the EG students. 
In brief, topic-based writing did contribute to the writing motivation of students in this study. This was expressed in the high proportion of positive responses towards topic-based writing activity.

Table 2. Results of EG learners' writing motivation

\begin{tabular}{|c|c|c|c|}
\hline Questions & Answers & Number & $\begin{array}{c}\text { Percentage } \\
(\%)\end{array}$ \\
\hline \multirow{2}{*}{$\begin{array}{l}\text { 1. Are you interested in writing } \\
\text { about ASD? }\end{array}$} & Yes & 34 & 80.95 \\
\hline & No & 8 & 19.05 \\
\hline \multirow{2}{*}{$\begin{array}{l}\text { 2. Do you think that writing } \\
\text { about ASD is helpful to you? }\end{array}$} & Yes & 31 & 73.81 \\
\hline & No & 11 & 26.19 \\
\hline \multirow{2}{*}{$\begin{array}{l}\text { 3. Do you read about the topic } \\
\text { before writing? }\end{array}$} & Yes & 38 & 90.48 \\
\hline & No & 4 & 9.52 \\
\hline \multirow{3}{*}{$\begin{array}{l}\text { 4. How many minutes do you } \\
\text { spend writing about ASD daily }\end{array}$} & More than one hour & 15 & 35.71 \\
\hline & About 45 minutes & 21 & 50.00 \\
\hline & Less than 20 minutes & 6 & 14.29 \\
\hline \multirow{2}{*}{$\begin{array}{l}\text { 5. Will you continue to write } \\
\text { about a topic? }\end{array}$} & Yes & 36 & 85.71 \\
\hline & No & 6 & 14.29 \\
\hline
\end{tabular}

\section{Results From Observations and Interviews}

The benefit of topic-based writing activity on learners' achievement and motivation was also obtained through observations and random interviews among EG students.

As far as what the researcher could observe, although at the first days of the course, ASD was a bit new to students, they were open to write on this topic. "I'm curious with ASD, it is new to me. I will write to learn more about it", "Writing about ASD, it sounds great and I will look for more information about this topic".

The students in EG spent around two weeks to be used to topic-based writing activity. At the beginning, the majority of students made short sentences in basic and easy language to write what they understood about ASD or to express their sentiments on writing.

Following is the example lines of one student writing an introductory paragraph at the first week of writing about ASD. Students were asked to use one of opening techniques for the introductory paragraph learnt in the lesson.

I never thought that one day I would write about autism like this. I don't know something about this topic. I have just hear from my friends that autistic people don't want playing with others. But, this afternoon, the teacher encouraged us to write about autism and I will write about this topic at the next 10 weeks of the course. I will read some articles and search the links about this topic that teacher have provided. Starting today, I will write to you what I know about autism. This is the road that lead me to autism. (Received on March, $8^{\text {th }}$, 2019/Week 1/T.N.P./Class K16.2). (The mistakes were italicized by the researcher.)

On that week, students were also encouraged to write about their thought about writing on ASD. Here is one of their writings.

To be honest, I don't know about ASD and I haven't written about ASD. I am afraid that I can not write well and frequently. However, the teacher said with_me to write because of it helps_my writing skill and she will show me my errors and help me correcting. I hope that everything will be good. (Received on March, $7^{\text {th }}, 2019 /$ Week 1/N.T.H.Đ./Class K16.2) 
After days of writing practice, the students in the EG showed their confidence in this skill. They could write more about ASD with longer paragraphs. Certainly, few mistakes still appeared in their writings. Following is the paper submitted after 5 weeks of writing learning. Students were asked to write about autism and use linking words as that week writing lesson required.

Some days ago, I watched some images related to activities on the world autism awareness day. Through stories of some parents, I realized that autistic children face many difficulties in their day activities. Firstly, it is $a$ language problem. There are many children who can speak only a few simple words. Moreover, there are children who only repeat others' words. In addition, many children cannot speak. Secondly, it is difficult eating habit. In fact, many children only eat some familiar foods instead of various of foods. Besides, there are children who are nervous to smell a certain kind of food. Furthermore, some children who do not know how to chew the food even after they are 7 or 8 years old. Finally, the challenges are in sleeping. Some children stay up until 2 a.m. before sleeping well. Additionally, some children can sleep only when they have a parent. In short, there are so many difficulties that autistic children face. (Received on April, $4^{\text {th }}$, 2019/Week 5/T.N.B./Class K16.2)

When finishing the first six weeks of the writing course, the EG students themselves created a cooperative learning environment naturally. During break time and after school, the researcher heard them to talk about writing and ASD with one another, such as: "How about your writing this week?", "Did you have the ideas for your writing?", and "What do you think about the obstacles of parents with autistic children?", etc. When was asked to correct mistakes for other before submitting the writing, students worked in pairs voluntarily to help each other. The researcher also realized that in Zalo group of EG and in some individual blogs, several students posted the writings that they thought to be excellent. They also connected with some parents having ASD children, they supported, liked and shared online activities to welcome the World Autism Awareness Day.

Interestingly, with detailed instructions, courageous feedback and open discussion from teacher to what students wrote, the bond between students and teacher was friendly. Students wanted to explore more about ASD in Phan Thiet City where they were living in by using snowball rolling technique to get acquainted with parents having autistic kids.

In order to know what assistance in the writing that students need from the teacher and to examine if the students were interested in this writing activity as well as if they continued this activity in the future, the researcher sometimes interviewed with EG subjects. The same following lines were often collected from interviews between researcher (R) and student (S). (On April, 15 ${ }^{\text {th, } 2009) \text { : }}$

$\mathrm{R}$ : Are you interested in writing about ASD in English?

S: Yes

$\mathrm{R}$ : What are the reasons why you like writing on this topic?

$\mathrm{S}$ : Because I can learn more vocabularies on this topic and I know something more about ASD. ASD is not what I were hear before like ASD children cannot learn anything.

R: Do you have any difficulties in writing?

S: I forget some structures

R: What can I do to help you?

S: I had too much help from you, when you replied with your feedback.

R: How often do you write?

S: About twenty minutes to an hour, maybe three to five times a week. 
R: What about other classmates? Do they love writing about ASD?

S: Of course, we discuss about writing when hanging out and they sent you what they wrote every week.

R: Thank you for what you share.

S: Not at all. Good bye, teacher. Hope to still see you on our Zalo group to help us with our writing.

R: Certainly. Bye.

This is another interview. (On April, 22 ${ }^{\text {nd }}, 2019$ ):

R: Do you like writing about ASD in English?

S: Yes, I like this topic and I like writing

R: Why?

$\mathrm{S}$ : Because, after reading, writing becomes not too hard for me. It is a so interesting task to do. Writing helps me review and practise what I learnt in class.

$\mathrm{R}$ : How about the difficulties in writing?

$S$ : if I have a chance to read before writing, then writing is not too difficult for me.

R: Do you have any suggestion?

S: Show me some more articles on this topic because I think there are many things to write about it.

R: Sure, I will. How often do you write?

S: About forty minutes a day, an hour and a half on Sunday.

$\mathrm{R}$ : Do your classmates love writing about ASD?

S: Yes, I think so. We are curious about this topic. We often talk about weekly subtopics and weekly comments from you.

R: Thank you.

S: Remember to send me the articles on ASD. Good bye, teacher.

R: OK. Good bye.

Nevertheless, not all students like writing on ASD. Some of them told researcher what they thought sincerely. (On April, 29 ${ }^{\text {th }}, 2019$ ):

Re: Do you like writing about ASD in English?

S: I don't like much

$\mathrm{R}$ : Can you tell me the reasons?

S: I like watching video clips than writing.

R: How about your classmates?

S: I found them discuss about writing online but I don't know much to say.

R: How often do you write?

S: Once a week, to submit the writing to you.

R: How many minutes do you spend writing?

$\mathrm{S}$ : About over an hour, including reading the parts in the article.

$\mathrm{R}$ : If you have any difficulties in writing, tell me and I will give you any help you need.

S: Thank so much, teacher.

R: Thanks for your answers.

S: You're welcome.

R: Bye.

S: Good bye, teacher.

The students' writing improvement in accuracy, fluency, and the length of paragraphs were observed and recorded by researcher. After each lesson, students had five days before 
submitting their writings to the researcher. However, the number of submissions after 5 days decreased clearly week by week. With the passing of week, most students sent papers after about 2 days. The researcher usually read and gave comments on their writings on every Sunday before the next class meeting came, on every Monday afternoon. Furthermore, the students often posted questions related to writing techniques and ASD. Not merely the teacher but also their classmates answered what they asked. Many students participated in answering and giving suggestions to others. After 11 weeks, what students could write was longer while the amount of mistakes reduced.

Here is what a student wrote on the last week of the writing course.

In conclusion, I wasn't fond of writing about ASD in English at the beginning of the course because I did not have any ideas about this topic and writing task was really hard to me. But, now I find it quite easier to write about ASD. My range of vocabularies is widened and writing makes me remember them. Being corrected by the teacher weekly helps me realize what are my errors and how to correct them. It is beyond my imagination because ASD used to be so strange to me. I will write and learn more about autism so that I can understand and share with autistic people the difficulties they are encountering. I'm going to explore this subject, probably through my classmates, whom now have certain insights on autism, through the teacher because I believe she knows about this field. Besides, I will search knowledge from books, newspapers, and the internet. In addition to studying theoretically, I will learn from what I can see in daily life. I will visit some autistic children with my classmates. I think that interacting with these people will help me better understand this syndrome. My wish is that more and more activities will be organized for kids with autism so that they have more social environment to communicate with and their families are somewhat happy. In addition, I hope to have more services in Vietnam that can support these children such as health care services, intervention centers, and integration schools. In short, I long for more attention from society to these disadvantaged children. (Received on May, $14^{\text {th }}$, 2019/Week 11/H.V.C./Class K16.2)

Here is one of the students' feelings at the last week of the course showing positive change in intrinsic writing motivation.

Now, I like writing and want to know more about ASD. In the next days, I will continue to write like the way I have done for 11 weeks. After writing more about ASD, I will choose another topic to write because writing about a certain topic is a good way to learn writing. However, I have to look for articles on the topic to read before writing and I need someone to help me correct the mistakes. My writing skill is better at the end of this course by writing about ASD. Most of us submitted the writing to you, discuss excitedly on the group and were grateful to you for correcting the mistakes for us. (Received on May, 14 ${ }^{\text {th }}$, 2019/Week 11/T.D.L./Class K16.2)

Here is one of the students' feelings at the last week of the course showing positive change in intrinsic writing motivation.

Now, I like writing and want to know more about ASD. In the next days, I will continue to write like the way I have done for 11 weeks. After writing more about ASD, I will choose another topic to write because writing about a certain topic is a good way to learn writing. However, I have to look for articles on the topic to read before writing and I need someone to help me correct the mistakes. My writing skill is better at the end of this course by writing about ASD. Most of us submitted the writing 
to you, discuss excitedly on the group and were grateful to you for correcting the mistakes for us. (Received on May, 14 ${ }^{\text {th }}$, 2019/Week 11/T.D.L./Class K16.2)

\section{CONCLUSION}

This study examined the effectiveness of topic-based writing with the assistance of reading material in improving writing motivation and ability of learners' writing, raising their love for the topic, and creating a close relationship between teachers and learners. Through reading and giving feedback to learners' writing, teachers can assess the competence level of each learner, and understand what they think and feel about the writing and the topic. This assists teachers to give learners useful help to grow out of the difficulties and adjust their teaching writing methods to be more suitable to most learners in class. Research findings show that topic-based writing activity left a significant impact on learners' writing. In order to obtain success when applying topic-based writing activity into the classroom, teachers of English should supply students with some reading material, give supportive feedback, and create interactive learning environment.

\section{REFERENCES}

Artof, S.D. (1992). Use of Personal Writing for Personal Growth. In Tin, T.B. (2004). Creative Writing in EFL/ESL Classrooms. Universiti Putra Malaysia Press.

Applebee, A.N. (1984), Writing and reasoning, Review of Educational Research, Vol.54, No.4,pp. 577-596.

Boscolo, P., Laura D. F. \& Michelle, B. (2007). Writing on an Interesting Topic: Does Writing Foster Writing? Studies in Writing; Writing and Motivation. Amsterdam: Elsevier.

Brown, M. (2009). Specialists speak out for autistic children: Look at Vietnam. Retrieved from http://www.lookatvietnam.com/2009/03/specialists- speak- out-for-autisticchildren.html.

Chanderasegaran, A. (2002). Intervening to Help in the Writing Process. RELC Portfolio Series 7.

CLAN (2010). Children's Hospital 1: Autism Project Report: Carings and living as neighbours (CLAN).

Emig, J. (1977). Writing as a mode of learning. College Composition and Comunication, 28 (2), 122-128.

Glazier, T.F. (1994). The Least You Should Know about English Writing Skills. USA: Harcourt Brace College Publishers.

Hamp-Lyons, L. \& Heasly, B. (2006). Study Writing (2nd Ed.). Cambridge: Cambridge University Press.

Hedge, T. (1991). Writing. Hong Kong: Oxford University Press.

Hidi, S., \& Mc Laren J. (1990). The effect of topic and theme interestingness on the production of school expositions. In Mandl H.,De Corte E., Bennet, N., and Friedrich, H.F. (eds), Learning and instructions: European Research in an International Context, Vol.2.2, Pergamon, Oxford, pp. 295-308.

Hidi, S., and McLaren J. (1991). Motivational factors and writing: The role of topic interestingness. Eur. J. Psychol. Educ. 6(2): 187-197.

Newell, G.E. (1984), Learning from Writing in Two Content Areas: A Case Study/Protocol Analysis. Research in the Teaching of English. Vol. 18, No. 3, pp. 265-287.

Richards, J.C., \& Renandya, W.A.(2002). Methodology in Language Teaching: An Anthology of Current Practice. Cambridge University Press. 
Spivey, N.N. (1997). The constructivist metaphor: Reading, writing, and the making of meaning. Emerald Group Pub Ed.

Spivey, N.N. \& King. J.R. (1989). Readers as Writers Composing from Sources. Vol. 24, No. 1, pp. 7-26. International Literacy Association and Wiley.

Stahl, S.A., Hynd, C.R, Britton,B. K. McNish, M.M, Bosquet, D. (1996). What Happens When Students Read Multiple Source Documents in History? Reading Research Quarterly, International Literacy Association.

Tho, L.N.M. (2000). A Survey of Writing Problems of USSH First-Year Students of English. Ho Chi Minh City.

Tin, T.B. (2004). Creative Writing in EFL/ESL Classrooms. Universiti Putra Malaysia Press.

Tuan, L.T. (2011). Teaching Writing through Genre-based Approach. Theory and Practice in Language Studies, Vol. 1, No. 11, pp. 1471-1478.

Vygotsky, L.S. (1978). Mind in Society: The Development of Higher Psychological Process. Cambridge, Mass: Havard University Press.

Weir, C.J. (1990). Communicative Language Teaching. GB: Prentice Hall International.

Wiley, J., \& Voss, J. F. (1999). Constructing arguments from multiple sources: Tasks that promote understanding and not just memory for text. Journal of Educational Psychology, 91(2), 301-311. 